原著 $\quad$ 三チチ鉛の行動毒性に関する実験的研究

岸玲 子*, 原 㴊 泉*, 池 田 聰 子*
三宅 浩 次*

\title{
THE EFFECTS OF TETRAETHYL LEAD ON BEHAVIOR IN RATS
}

\author{
Reiko KISHI,* Izumi HaRABUCHI,* Toshiko IKEDA* \\ and Hirotsugu MIYAKE*
}

The effects of $10 \mathrm{mg} / \mathrm{kg}$ and $5 \mathrm{mg} / \mathrm{kg}$ intraperitoneally administered triethyl lead on rats were observed through measurement of the following : changes in body weight, passive aggressiveness, wheel running activity, the performance level of Rota-Rod Treadmill, and emotional responses in the open field.

The results obtained were as follows:

1. Weight losses of TEL-treated rats were recorded from 2 days after injection to 20 days after injection.

2. Scores of passive aggressiveness were drastically increased following administration of TEL. Maximum passive aggressiveness was observed 4 days after injection and it continued until 13 days after injection.

3. Wheel running activity was decreased for 2 days after injection. It was observed that TELtreated rats showed extreme reaction on the wheel running activity test for about 30 days after administration.

4. Endurance on the Rota-Rod Treadmill was significantly reduced in the $10 \mathrm{mg} / \mathrm{kg}$ group.

5. The amount of defecation, ambulation and rearing of the treated group as measured by covariance analysis did not differ from that of the controls.

6. The whole time course of intoxication and the precise measurement of neurotoxicity due to TEL could be followed using the techniques of behavioral toxicology.

\section{I. 緒言}

有機鉛は，従来てンチ・ノッキング刘としてガソリン に微量 $(0.08 \sim 0.1 \%)$ の割合で混入されていたが，水 飞不溶, 揮発性が高いため主として呼吸器, 皮缯, 消化 器などの経路を維て急速に体内に侵入し，生体に猛毒性 を有することは古くから知られている ${ }^{1,2)}$.

わが国では，1938年に森崎3により初めて中毒事例が 報告され，第 2 次大戦中，中毒例が頻 発 し，更に，戦 後，米軍の放出による中毒事例が多発したことが赤塚 によって詳練に報告されている。また，近年，ガソリン 詝蔵タンクの清掃作業や運搬中のタンカーに括ける中毒

* 札幌医科大学公夏衙生学教室 昭和59年11月 12 日受付

* Department of Public Health, Sapporo Medical College

Received for publication, November 12, 1984
例などが報告されている5,6).

四エチル鉛中毒の初期症状としては，不眠，倦急感が あり, 進行すると手指の振せん，腱反射六進, 記銘力減 退がみられ, 幻覚妄想状態, 精神運動元奮, 痤繁発作, 高熱などを生ずると致命率が高いといわれる5).

四エチル鉛の代謝と毒性については，体内に吸収され た四ェチル鉛は，肝で速やかに水溶性の三ェチル鉛に代 謝され，主に二エチル鉛または無機鉛の形で尿や霬便中 に排泄される 7,8$)$ ，一般に，四エチル鉛中毒の場合，無 機鉛中毒の典型的症状は久けているため，中毒の発症機 序は異なると考えられている9゙.乙かし，有機鉛がどの ような機序で毒性をあらわすのかといった毒性発現のメ カニズムや最小作用量はどのくらいなのか，低漶度で長 期間暴露を受けた場合の毒性などについては，またよく わかっていないか.

有機鈆中毒に和いて，最も強い障害が現われるのは中 枢神経系であることから症状の精密な分析や毒性の倹討 
に関して，行動中毒学的方法が近年いくつか試みられて いる ${ }^{10 \sim 13)}$. 行動中毒学の手法は毒性の鋭敏な指標の一つ として許容湍度やいわゆる no-effect-level の設定にも利 用されつつある ${ }^{14)}$. いくつかのパフォーマンス・テスト を組み合わせて用いることにより毒性の定量化や，中毒 の発現および消失についての経時的な钼察が可能にな る.

本研究は，アルキル鉛急性中毒の場合の量反応関係に ついて明らかにすることを目的として，四ェチル鉛の代 謝産物で中枢神経毒性を有寸る本体と考えられている三 エチル鉛を用いて，三ェチル鉛を 1 回投与した場合の毒 性を行動中書学的な手法を用いて检討した.

\section{II. 方 法}

\section{1. 実験動物と投与方法}

ウィスター系雄性ラット（平均体重 $431.7 \pm 33.5 \mathrm{~g}$ ) を用い，体重あたり $0 \mathrm{mg}$ （生食投与, 対照群， $n=9$ ), $5 \mathrm{mg} / \mathrm{kg}(n=9), 10 \mathrm{mg} / \mathrm{kg}(n=10) の$ triethyl lead を 腹腔内K 1 回投与した. 動物は室温 $25 \pm 1^{\circ} \mathrm{C}$ の飼育室 で 7:00 19:00(暗)，19:00 7:00(明) の昼夜逆転 リズム下で $2 \sim 3$ 匹ずつ飼育し，水と䬨料は自由摄取さ せた。

\section{2. 行動中毒学的祫索}

以下の 5 項目について観察を行った. (1)体重, (2)Passive Aggressiveness ${ }^{15)}$ (被刺激性), (3Rota-RodTreadmill による平衡機能 テスト, (4)Activity Wheel (回転輪)による自発的行動量, (5)オープン・フィール ド・テスト（情動性のテスト）

(1) Passive Aggressiveness (被刺激性) のスコフ Passive Aggressiveness の指標としては，外部刺激と して(1)背中に架気を吹きける，(2)とゲをガラス棒で触 れる，(3)背中をガラス棒で触れる，(4)身体を片手でつか むの 4 刺激を用い，それぞれに対する動物の反応を0か ら3までの 4 段階にスコア化して湘定した。たとえば， (1)背中に空気を吹きつけた場合，(1)反応なしを0点，(1) 体を硬直させるか耐えるが 1 点，鳴き声を上げ跳び上

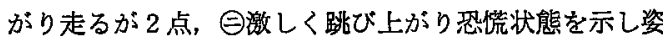
势を保てないが 3 点とした. したがって 4 刺激に対する 反応性としては最高が 12 点, 最低は 0 点の間の点数で 動物の被刺激性を表した。

(2) Activity Wheel Test (活動性テスト)

Activity Wheel Test は, 金網製の幅 $7 \mathrm{~cm}$, 直径 60 cm の回転輪を用い，車輸には 5 極のカムがついており 動物が輪の中を移動すると，回転ごとにマイクロ・スイ ッチの回路が閉じて回転数が記錄される. Activity
Wheel は3 台用意し，対照群と投与群（2 用量）の3 群を常に同時刻に測定した。測定は 1 日 30 分間，11日 間行って Activity Wheel K動物を馿化し安定した回転 数が得られるよらになったところで三ェチル鉛の投与を 行った.

(3) Rota-Rod Treadmill による平衡機能テスト

UGO Vasile 社製の Rota-Rod Treadmill 飞より 8 $\mathrm{rpm}$ の回転数でラットがシリンダーからら落下するまで の時間を測定した. この場合も投与前にそれぞれのネズ ミが安定したスコアを示すようになるまで訓練してから 三エチル鉛を投与し，每日一定時間に 1 匹むたり 3 試行 のテストを行ってその平均を求めた.

(4) オープン・フィールド・テスト

動物の情動性と関係がある指漂の一つとして Broadhurst $^{16)}$ らの方法によりオープン・フィールドに括ける 探索行動を通過区画数と後肢立ち上り回数で測定した. 使用したオープン・フィールドは直径 $65 \mathrm{~cm}$, 灰白色の 円形テープルで 1 区画 $133 \mathrm{~cm}^{2}$ の面積の等しい25 区画 から成り，100W の白色光でテーブル面のみを照らし た. ヘンドリングした動物を毎日一定の時間に装蹎中央 部に実験者の手によって静かに置いてから2分間におけ る通過区画数と後肢立ち上り回数を湘定した. 投与前の 成績は 2 日間の平均值でまた投与群る 1 日目と 2 日目，

5 日目と 6 日目の 2 日間の平均値で求めた。

以上の(1) (4)の行動中毒学的钼察は, それぞれ暗期 （動物の活動期）の決まった時刻に行った。

\section{3. 病理組織学的検索}

三エチル鉛を投与し，行動学的検索を 30 日間続けた 後，動物を屠殺し病理組織学的に検索を行った，動物は Pentobarbital Sodium 麻酔下, 脳, 筒鹃, 肝, 腎を剔 出した. 各臟器はバラフィン包埋法にて切片を作製し, Hematoxylin-Eosin 染色および水 Klüver-Barrera 鲢鞘 染色, Bodian 染色を行った.

\section{III. 桔 果}

\section{1. 一般的行動}

投与の 24 時間啳, 投与群のちちとくに $10 \mathrm{mg} / \mathrm{kg}$ 投 与群では動きが不活発でじっとらずくまっていることが 多かった. しかし，明らかな歩行障害や失調などの所見 は，投与群のいずれのラットでも認められなかった. 10 $\mathrm{mg} / \mathrm{kg}$ 投与群のらち 10 匹中 1 匹が 20 日目に死亡した。

2. 体 重

それぞれのネズミの投与前の前值と比較して 2 日目よ り体重減少が顕著に認められた. $5 \mathrm{mg} / \mathrm{kg}$ 投与群では $5 \%$ 位の減少, $10 \mathrm{mg} / \mathrm{kg}$ 投与群では体重減少のピーク 

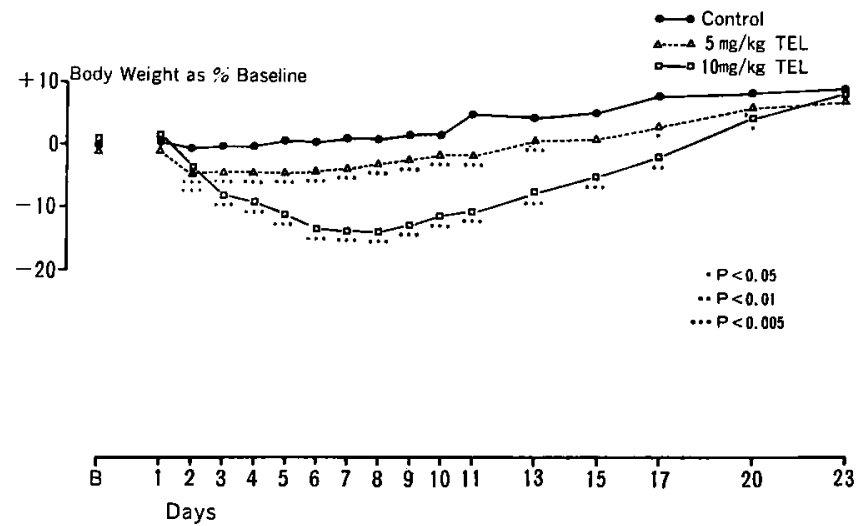

Fig. 1. Changes of body weight of rats exposed to TEL.

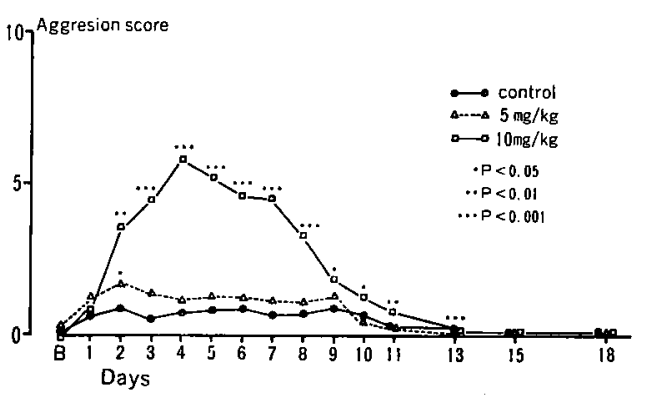

Fig.2. Effect of TEL on aggression.

は投与後 8 日目で, 約 $13.8 \%$ の減少を示した (Fig.1). 3. Passive Aggressiveness（被刺激性の穴進）

$10 \mathrm{mg} / \mathrm{kg}$ 投与群では，2 日目以降スコアが上昇し 始め，4日目のピーク時には平均スュフ 5.8 を示した (Fig.2). 経過中に最高スコアが8を示したラットす 10 匹中 4 匹おり，この場合，背中に空気を吹きつけると激 しく跳び上がり恐慌状態を示す，身体を片手でつかむと 逃げまわり粦をむき出してかむなど，実験者が手で動物 をつかむのが困難な汪どの攻撃性が観察された. スュフ を対照群と比較検定すると，投与後第 2 日目から第13日 目まで対照群の平均 $0.6 \sim 0.9$ に比較すると有意の高值 を示した (Fig.2).

これに対し， $5 \mathrm{mg} / \mathrm{kg}$ 投与群では経過中スコア 3 か らスコフ 4 を示すネズミが9 四中 4 匹いたが，群全体と してみると，対照群との差はそれほど大きくはなく，第 2 日目にのみスコアが $1.7 \pm 0.8$ で有意の差を示した。

4. Activity Wheel Test による活動性の変化 対照群では，全観察期間（30日間）の9匹の平均活動
量の 95\% 信頼限界を求めると, 対照群では投与前に比 べ平均 $91.7 \%$ ，標準偏差 $38.3 \%$ で，変動幅は比較的小 さく安定したパーセンテージを示した (Fig.3). これに 対し投与群では，とくに第 1 日目と第 2 日目の自発的な activity は非常に低く，10 mg/kg 投与群では第 1 日目 は前値の $14.5 \pm 13.1 \%$ ，第 2 日目は前値の $50.2 \pm 41.3$ \%であった。 また $5 \mathrm{mg} / \mathrm{kg}$ 投与群では第 1 日目 $31.5 \pm$ $15.7 \%$ ，第 2 日目 $94.9 \pm 51.4 \%$ で投与前値に比べて第 1 日目のみ低下を示した，投与群のらち比較的低濃度の $5 \mathrm{mg} / \mathrm{kg}$ 投与群では，投与直後自発行動の抑制が 観察 された後, 投与後第 4 日目から第 9 日目までは対照群に 比べ逆に有意の上昇が認められた. $10 \mathrm{mg} / \mathrm{kg}$ 投与群で は, 10匹の平均の活動性では第 3 日目以降, 有意差は認 められなかった。

平均值ては差は認められなかったものの, 個々の動物 の活動性を詳細に㭘討してみると, 対照群の動物は, 前 述のように活動性の変動幅が小さいのに対し，投与群で は極端に高い活動性や低い活動性を示す個体の数が多 く, 全覞察期間 (30日) を通してて, 信頼限界の幅から逸 脱する個体数が有意に多い日がみられた（Table 1 およ び Fig.3).

\section{Rota-Rod Treadmill による平衡機能}

Rota-Rod Treadmill の成縝は，投与前の成續を $100 \%$ とした場合の投与後のパーセント，バフォーマンスで表 わしている (Fig.4).

対照群では，平均すると 99.5 138.6\% と投与前より 投与後のほらがせしろよい成績を示した， $5 \mathrm{mg} / \mathrm{kg}$ 投与 群も対照群とほぼ同様の傾向が観察された.これに対し $10 \mathrm{mg} / \mathrm{kg}$ 投与群では，10 匹の平均で第 1 日目 $75.1 \pm$ $40.3 \%$ ，第 2 日目 $72.4 \pm 33.7 \%$ ，第 3 日目 $84.4 \pm 33.7$ 


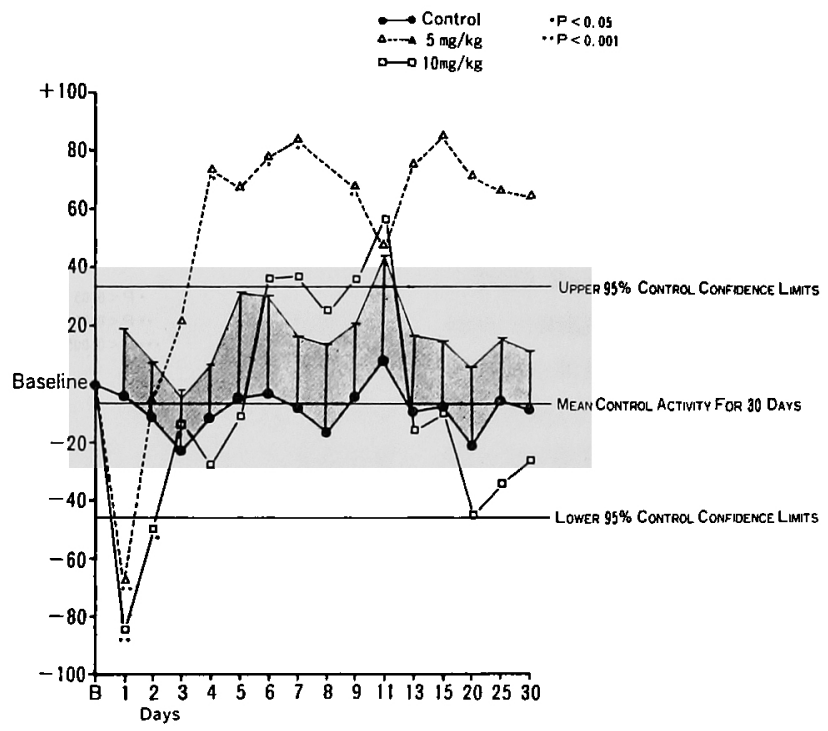

Fig. 3. Treadmill activity of rats as difference from baseline.

Table 1. Number of rats with outskirt of $95 \%$ control confidence limits in Treadmill test.

\begin{tabular}{lccccccccccccccccc}
\hline & \multicolumn{11}{c}{ Group } & \multicolumn{11}{c}{ Days after exposure } \\
\cline { 2 - 14 } & 1 & 2 & 3 & 4 & 5 & 6 & 7 & 8 & 9 & 10 & 11 & 13 & 15 & 20 & 25 & 30 \\
\hline Control $(n=9)$ & 0 & 1 & 2 & 0 & 2 & 1 & 1 & 1 & 0 & 0 & 1 & 0 & 0 & 1 & 1 & 0 \\
$5 \mathrm{mg} / \mathrm{kg}$ TEL $(n=9)$ & $8^{* * *}$ & 3 & 5 & $6^{* * *}$ & 6 & 5 & 2 & 4 & $6^{* * *}$ & 4 & 5 & 4 & $7^{* * *}$ & $6^{*}$ & 4 & $5^{* *}$ \\
$10 \mathrm{mg} / \mathrm{kg}$ TEL $(n=10)$ & $10^{* * *}$ & 5 & $6^{* *}$ & $6^{* *}$ & $8^{* *}$ & 5 & 5 & $7^{* *}$ & $7^{* * *}$ & 3 & 3 & $6^{* *}$ & 3 & 4 & 3 & 1 \\
\hline
\end{tabular}

Significantly different from control animals by the Fisher exact probability test : ${ }^{*}, p<0.05 ; * *, p<0.02$; $* * *, p<0.005$.

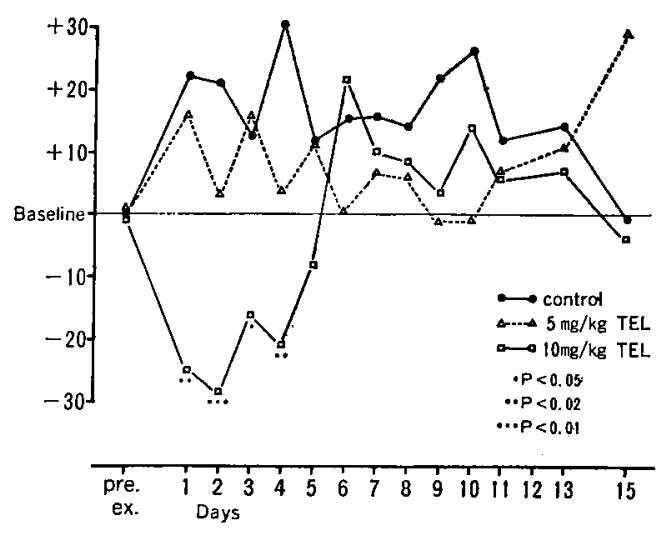

Fig.4. Effect of TEL on Rota-Rod Performance.
$\%$ ，第 4 日目 $79.7 \pm 33.8 \%$ と， -30\% 近いパフォー ンスの低下を示し，対照群と比較して有意の低下が認め られた。

$$
\begin{aligned}
& \text { 6. オープン・フィールド・テストによる情動性 } \\
& \text { オープン・フィールドKおける } 2 \text { 分間の区画通過数は }
\end{aligned}
$$
個体差が非常に大きかった. 対照群, 投与群とるに，投 与前に比べ投与後第 1 日目之第 2 日目の平均值はやや低 く，第 5 ，第 6 日目は投与前とほぼ同じという結果を示 し，投与前值を共変量として共分散分析を行ったが有意 の差は認められなかった。眖䔬数，身つくろい数，後肢 立ち上がり回数でる有意差はなかった（Table 2).

\section{7. 病理組樴学的検索}

各葴器とも肉眼的には著变は喼められなかった. 肝・ 腎には，とくに組織学的に病変は諗められなかった. 神 経系では，大脳皮質では対照群に比ぺて特別な神経細胞 
Table 2. Effects of triethyl lead on open field behavior.

\begin{tabular}{clllll}
\hline \multicolumn{1}{c}{ TEL dose } & Ambulation & Rearing & Preening & Defecation \\
\hline \multirow{2}{*}{$0 \mathrm{mg} / \mathrm{kg}$} & pre injection & $25.1 \pm 15.1$ & $0.5 \pm 0.6$ & $0.1 \pm 0.2$ & $2.0 \pm 1.6$ \\
& 1-2 days after inj. & $17.4 \pm 12.3$ & $0.4 \pm 0.8$ & $0.0 \pm 0.0$ & $0.6 \pm 0.7$ \\
& 5-6 days after inj. & $24.2 \pm 21.2$ & $0.4 \pm 0.8$ & $0.1 \pm 0.2$ & $0.3 \pm 0.8$ \\
& pre injection & $24.1 \pm 15.1$ & $0.6 \pm 0.2$ & $0.6 \pm 0.2$ & $1.7 \pm 1.0$ \\
$5 \mathrm{mg} / \mathrm{kg}$ & $1-2$ days after inj. & $13.1 \pm 10.8$ & $0.3 \pm 0.5$ & $0.2 \pm 0.5$ & $0.2 \pm 0.3$ \\
& 5-6 days after inj. & $24.2 \pm 21.2$ & $0.4 \pm 0.6$ & $0.4 \pm 0.6$ & $0.0 \pm 0.0$ \\
& pre injection & $25.8 \pm 14.8$ & $0.4 \pm 0.5$ & $0.1 \pm 0.2$ & $1.2 \pm 0.8$ \\
$10 \mathrm{mg} / \mathrm{kg}$ & $1-2$ days after inj. & $22.8 \pm 32.8$ & $0.3 \pm 0.6$ & $0.1 \pm 0.3$ & $0.2 \pm 0.6$ \\
& $5-6$ days after inj. & $33.6 \pm 15.8$ & $0.8 \pm 0.9$ & $0.1 \pm 0.2$ & $0.6 \pm 0.8$ \\
\hline
\end{tabular}

Summary of 4 open field measures : ambulation (i.e., locomotor activity); rearing (i.e., vertical activity); preening (i.e., grooming behavior); and defecation (i.e., number of fecal boluses). All values are presented as mean \pm S.D.

の障害は認められなかった，大脳白質，小脳，脳幹部の 核，春噵化す著变恃認められなかった。

\section{IV. 考察}

有機鉛は揮発性であることにより蒸気として容易に呼 爱器より吸収されるまた液体として消化管よりの吸収 も容易である，四収された有機鉛は，最初は無機鉛とは 全く異なった形式で身体各組織に沈着する.すなわち有 機鉛俚血液脳関門を容易飞通過し，脳化高濃度飞移行す る.三ニチル鉛の場合も，肝，血液，腎，脳の濃度が高 く,これらの臟器からの消失の速度は荤いといわれる7》。

Cremer ${ }^{17,18)}$ は，アルキル鉛の代謝之毒性について四 エチル鈶が，体内ですみやかに分解されて三ェチル鉛に 変わること，四エチル鉛から三ェチル鉛への分解は肝細 胞の滑面小胞体で生ずること，三ェチル鈶性ぶどう糖酸 化，ピルビン酸酸化を強く抑制すること，四ェチル鉛投 与ラットで三ェチル鉛の贜器分布は三ェチル鉛そのるの の投与と類似していることなどを観察し，四ェチル鉛の 毒性は四エチル鉛の代謝産物である三ェチル鉛によるも のと考えた．四エチル雓自身にる中枢神経障害作用があ るといら報告すあるが'19)，本実験でみられるよらな特㣲 的な神経症状は四エチ儿鉛暴露後発現までに一定期間を 要することから，中枢神経系の毒性性主として三ニチル 鈶の中枢神経系への蓄積によるすのではないかと考えら れている.

本実験では，水溶性の三ェチル鉛そのるのを腹院内投 与し，量反応関係を検討した．実鈳に先だち，予備実験 として三ェチル鉛 $20 \mathrm{mg} / \mathrm{kg}$ ，および $15 \mathrm{mg} / \mathrm{kg} 1$ 回投
与を行ったが，いずれの動物る，投与後 24 時間以後， 動作が非常に不活発になり急激な体重減少を経て 48 時

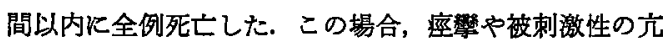
進恃全く観察されなかった。 また $5 \mathrm{mg} / \mathrm{kg} 3$ 日連続（合 計 $15 \mathrm{mg} / \mathrm{kg}$ ) 投与した動物では, 数日後から激しい全 身痤摩，振せんを示し，両下肢の麻痷を呈し，投与後数 十日以内に死亡した。

それらに対して，本実験の $10 \mathrm{mg} / \mathrm{kg}$ 投与群では，第 2 日目以降，体重減少傾向があり，Activity Wheel Test でも，初めの数日は活動性が顕著に抑制されていたが， その後被刺激性の六進の出現ととすに動物によっては極 端な活動性の上昇あるいは低下が顕著に認められた。 た Rota-Rod Treadmill Kよる平衡機能テストに物いて は, 対照群と三ェチル鉛 $5 \mathrm{mg} / \mathrm{kg}$ 投与群では, 暴露後 る練習奻果によると思われるテスト成續の向上が見られ たのに対 し, $10 \mathrm{mg} / \mathrm{kg}$ 投与群では三エチル鉛投与後第 I 日目から第 4 日目までパフォーマンスの有意な低下が 認められた. $10 \mathrm{mg} / \mathrm{kg}$ 投与群に比へ $5 \mathrm{mg} / \mathrm{kg}$ 投与群 では平衡機能の障害む観察されず, 被刺激性の亢進の程 度るかなり軽いが, Activity Wheel Test では，投与初 期の自発行動の抑制に引き続いて以後，むしろ活動性の 元進が認められこの影響は投与後 2 週間以上にわたって 観察された.

アルキル鉛中毒の臨床症状として Kehoe ${ }^{1,2)}$ は軽症で は, 頭痛, 興窗, 不稳, 不安, 倦意, 悪夢, 不眠, 消化 器症状として食欲不振，嘔吐，下淿などをあげ，重症例 では上記の前躯症状飞続いて幻覚, 譫妄, 强烈な恐怖体 験，自殺企図などがみられると報告している．また神経 
症状としては，四肢粗大振せん，腱反射六進が特徵的

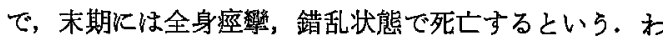
れわれの実験結果をヒトの中毒例付対応させて考劣ると $5 \mathrm{mg} / \mathrm{kg}$ 群が人体の場合の軽症例, $10 \mathrm{mg} / \mathrm{kg}$ 性中等度 の症例， $15 \mathrm{mg} / \mathrm{kg}$ 以上では重症例保相当すると言光よ 5 .

Schroeder らは20), 四エチル鉛の $\mathrm{LD}_{50}$ 汇ついてラッ トの経口投与では $\mathrm{LD}_{50}$ は $12.3 \mathrm{mg}$ で，16 $\mathrm{mg} / \mathrm{kg}$ 投 与では致死率 $100 \%, 10 \mathrm{mg} / \mathrm{kg}$ 投与では 18 匹中 2 匹 が死亡， $8 \mathrm{mg} / \mathrm{kg}$ 以下では死亡動物はいないと報告し ている.われわれの今回の实験でも $10 \mathrm{mg} / \mathrm{kg}$ 投与では 10 匹中 1 匹が死亡し， $15 \mathrm{mg} / \mathrm{kg}$ 以上では全例死亡して いることから，四エチル鉛も三エチル鉛もラットの $\mathrm{LD}_{50}$ にはそれ活ど大きな違いはないのではないかと思われ る. しかし Springman らは212，動物に四ェチル鉛を投 与すると他覚症状として振せんが現われるが，振せんの 発現は三エチル鉛のほうが四エチル鉛より少量の投与で 出現すると報告して战り，四エチル鉛と三ェチル鉛の毒 性の差異については今後更に検討を要する。

四エチル鉛中胥で 24 時間以内に死亡した事例では, すでに血中鉛の約 $60 \%$ が三ェチル鉛であったとされ る ${ }^{21)}$. 一方四ェチル鉛は一た儿代謝されて三ェチル鉛に なると，その排泄は幄く，投与後数日間でる眏器中三ニ チル鉛の量の変化がないことが示されている22,233. 本実 験でる，Rota-Rod Treadmill 飞よる平衡機能は，投与 後比較的早く，5日目には回復していたものの，「被刺 激性の充進」は，投与後かなり日数を経ても，奶照群に 比べて有意差があったこと，Activity Wheel Test でみ られた極端な活動性の光進や低下が 1 か月近く続いてい ることなどから，三エチル鉛の中权神経系への影響は一 回投与の場合でるかなり長くまで残るのが特徽の上うに 思われる。

松本らは244，四エチル鉛を投与したラットで睡眠覚醒 サイクルに及济す影響について脳波学的飞検討し，四エ 千ル鈶 $10 \mathrm{mg} / \mathrm{kg}$ 投与では slow wave sleep（徐波睡

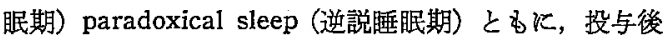
5 日目までは減少し，徐波睡眠期については，その後回 復傾向がみられたが，逆説睡眠期については，投与後30 日間を経過しても投与前值に比較して有意に少なく，完 全には回復しないと報告している．今回の実験でる，極 端な活動性の上昇や低下が 1 か月近くも続いたのは松本 らの指摘した睡眠，覚醒像の変化と何らかの関係がある のかる知れない.

有機鉛を投与した実験動物で，行動中毒学的方法に上 る毒性の恰討がこれまでいくつか陚みられている10 13).
Bulloch らは10)，四エチル鉛を連続 8 日間，合計で 15 $\mathrm{mg} / \mathrm{kg}$ 投 与乙，最終投与の 4 日後から水中 T字型迷路 テストを行っている. 四エチル鉛投与動物では最初の 4 日間の訓練試行でのみ有意差が認められたが，その後の 平均逃避時間炕差は認められなかったと報告している. 一般飞「水中に和けるT字型迷路テスト」の場合, 学習 行動とは言っても運動機能が大きく関与しているので， 運動系の機能障害の影響子無視でない. Bulloch 5の 成續は，われわれの Rota-Rod Treadmill 飞よる平衡機 能テストで, パフォーマンスの低下が三ェチル鈶投与後 数日間観察された後, 投与前の成績さで回復している実 験結果と符合する.

また Avery らは11)，四ェチ儿鉛 2，4，6，8,10 mg/ $\mathrm{kg}$ 胃内比 1 回投与後, FR 5 (定率強化学習) 之負強 化による升別回避学習の習得過程および保持に及ぼす影 響とオープン・フィールド・テストによる情動性の変化 を検討している. その結果, 四ェチル鉛投与群では, 対 照群に比較して，升別回避学習の習得過程汇遈延が見ら れ，学習の保持過程中にも誤反応の多発がみられたこと を報告し，一方，オープン・フィールド・テストによる 情動性には差がないことから，四エチル鉛が，動物の情 動性火影響を与兄ることなく，実験動物の学習中記憶そ のるのに影響を与えていると結論している。しかしの 場合, 動物の例数が少ない5えに，著者らの実験では， オーブン・フィールド・テストでは対照群との間有意 の当は認められないが, Passive Aggressiveness のス コフでは大きな差があり，Activity Wheel Test に扎い てる極端な活動性の六進や隇少などが みられた事実か ら，オープン・フィールド・テストだけで動物の情動性 飞影響はないと結論つけけることはできないと思われる。

本笑験で恃，比較的高濃度の三ェチ儿鉛を投与し，明 らかな行動上の変化を認めたにるかかわらず，病理学的 検索では，光顕レベルでは特記すべき所見恃揌められな かった.

中野ら ${ }^{25)}$ は, 石油タンクの清掃作業に從事し, 如覚妄 想状態など典型的な四エチ儿鉛による中权神経症状を呈 して発病後 19 日目に死亡した 1 剖検例の病理所見につ いて報告し，病理学的に最も特徽的な所見として，中权 神経系全般の小血管，毛細血管の中膜の障害をあげ，次 にそれに付随する散在性または巣状の海綿様変性が，と く《海馬周辺部, 小脳白質および胸䯣の後索に顕著に認 められたと記述している，致死量变たは致死量近い四 エチル鉛を投与された实駼動物でも，大脳辺縁系，とく 飞海馬回之梨状葉選択的飞神経細胞の壞死性の病变が 顕著であったといら報告が Niklowitz ${ }^{26)}$ 呿よび赤井 
ら 27)にっってなれている。

有機鉛の神経組穖に対する作用の本態については，現 在までほとんど解明されてはいない.最近 Hong ら は，三エチル鉛 $2.5 \mathrm{mg} / \mathrm{kg}$ を 5 日間連続投与されたラ ットの海馬, 中隔, 前頭葉では, 投与後 8 日間, メター エンケファリン, Substance P の低下が認められること から，三エチル鉛による中权性の痛覚鈍麻は, これら大 脳辺洮系の神経ペブタイドの変化が関連しているのでは ないかと報告している、一般に，海馬，中隔，扁桃核等 を含めた大脑辺緑系は，大脳皮質や視床下部への線䧽連 絡を介して動物の情動性や，外部環境刺激に対する反応 性などと密接な関係があるといわれている29,30)，したが って，本実験で観察された三エチル鉛投与動物の「被刺 激性の強い六進」や「活動性の極端な変化」など, 三工 チル鉛による特徽的な神経症状む, それらの部位の機能 的な障害と何らかの関連があるすのと推察される.

$$
\text { V.むとめ }
$$

本研究では，三ェキル鉛の急性中毒を，行動中毒学的 方法を用いて行い, 病理組織学的には中权神経系に器質 的な変化を認めなかったにすかかからず，「Passive Aggressiveness」や，「Activity Wheel Test К拉ける活動 性の極端な亢忘進や低下」などの三ェチル鉛による特異な 影響を検出した.

量一反応関係からみると, 三エチル鉛 $5 \mathrm{mg} / \mathrm{kg} 1$ 回 投与群では, Rota-Rod Treadmill による平衡機能の障 害は認められなかったが, Activity Wheel Test で活動 珄の亢進が観察された。 $10 \mathrm{mg} / \mathrm{kg}$ 投与群では, 平衡機 能障害と被刺激性の著しい元進および活動性の極端な元 進と低下を認めた. $15 \mathrm{mg} / \mathrm{kg}$ および $20 \mathrm{mg} / \mathrm{kg}$ 投与群 では特有の中枢神経症状を示さないらちに，急激な体重 減少後, 投与後数日内に死亡した.

行動中毒学的な手法を用いることにより三エチル鉛の 中毒症状の発現特よび消失等の経時的な過程についての 定量的な把握を行いらることを示した.

本研究の実施にあたり，聖マリアンナ医科大学公揫衛生学教 室から三ニチル鉛をご提供いただいた. ご助言，こ挼助を睗っ た山村行夫教授，荒井二三夫先生，吉田秢先生に梁謝いたしま t.

また，病理組識学的検索にご協力をいただいた北海道大学医 療技街短期大学部中村仁志夫助教授 および 贵重なご示惨をくだ さった産業医学総合研究所有藤平八郎博士に感謝いたします.

\section{文献}

1) Kehoe, R.A.: Tetra-ethyl lead poisoning, clinical analysis of a series of nonfatal cases, J.A.M.A., $85: 108-110,1927$.

2) Kehoe, R.A.: Toxicity of tetraethyl lead and inorganic lead salt, J. Lab. Clin. Med., 12 : 554$560,1927$.

3）秝崎英夫：四ェチル鉛の臨床例，精神神経学䧴誌， 42 ： $572-579,1938$.

4）赤㙇京治：四エチル鉛中毒, 産業医学, 15：3-66, 1973.

5）山村行夫, 高房 淳, 平山二三夫, 山内 博, 吉田 稳:

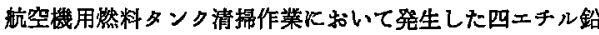
中啬, 業医学, $17: 223-235,1975$.

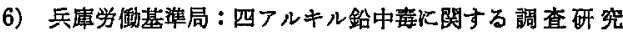
(B丸Kおける中專事例報告)，1969。

7) Bolanowska, W. : Distribution and excretion of triethyl lead in rats, Br. J. Ind. Med., 25: 203$208,1968$.

8）荒井二三夫，山村行夫，吉田 稔：四エチル鈶投与ウサ

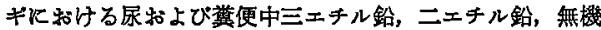
鉛排泄沉つい, 産業医学, $23: 496-504,1981$.

9) Buck, J.S. and Kumro, D.M.: Toxicity of lead compounds, J. Pharmacol. Exp. Ther., 38 : 161$172,1930$.

10) Bullock, J.D., Wey, R.J., Zaia, J.A., Zarembok, I. and Schroeder, H.A., Effect of tetraethyl lead on learning and memory in the rat, Arch. Environ. Health, $13: 21-22$, 1966.

11) Avery, D.D., Cross, H.A. and Schroeder, T. : The effects of tetraethyl lead on behavior in the rat, Pharm. Biochem. Behavior, 2 : 473-479, 1974.

12）川森正夫，松本一弥，松井知子：四エテル雓中毒関す る実験的研究（第 1 報）念性中症状の発現状況之自発行 野量の变化, 杏林医会誌, $14: 3-11,1983$.

13）松井知子，松本一弥，川森正夫：四エチル鉛中毒海閏す る夷験的研究 (第 2 報) ラットのオベラント行動に及ぼす 影響，杏林医会誌，14：129-135, 1983.

14) Xintaras, C., Johnson, B.L. and de Groot, I. (eds.) : Behavioral Toxicology-Early Detection of Occupational Hazards, NIOSH, 1974.

15）中村圭二, G. シビンデン，L.O. ランドール：向精神 薬の薬理, 78-86, 朝合書店, 東京, 1971.

16) Broadhurst, P.L. : Application of biometrical genetics to the inheritance of behaviour, in Personality, H.J. Eysench (ed.), Vol. 1, 3-102, Routledge \& Kegan Paul, London, 1960.

17) Cremer, J.E. : Biochemical studies on the toxicity of tetraethyl lead and other organolead compounds, Br. J. Ind. Med., 16: 191-199, 1959.

18) Cremex, J.E. and Callaway, S. : Further studies on the toxicity of some tetra and triethyl lead compounds, Br. J. Ind. Med., 18 : 277-282, 1961.

19）曼谷川弘道：公害関連物質の䝴性，159-162, 講談社方 イェンティフィク, 東京, 1974.

20) Schroeder, D., Avery, D. and Cross, H.A. : Tetraethyl lead dose response curve for mortality in laboratory rats, Experientia, $28: 923-924,1972$.

21) Springman, F., Bingham, E. and Stemmer, K.L.: 
The acute effects of lead alkyls, Arch. Environ. Health, $6: 469-472$, 1963.

22) Hayakawa, K. : Microdetermination and dynamic aspects of in vitro alkyl lead compounds (Part 2) Studies on the dynamic aspects of alkyl lead compounds in vitro, Jpn. J. Hyg., 26(6) : 526535, 1972.

23) Bolanowska, W., Pitrowski, J. and Ganczynski, H. : Triethyl lead in the biological materials in cases of acute tetraethyl lead poisoning, Arch. Toxikol., 22 : 278-282, 1967.

24）松本一弥，昖井知子，川森正夫：急性四エチル鈶中四の 実験的研究 (第 1 報) 四ェチル鉛がラットの睡眠-営醒サ

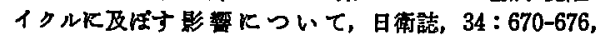
1979.

25）中野隆雄，今枝 実，竹内知夫，猪㖽 正：急性四エ

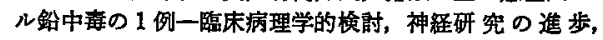
$22: 376-385,1978$.
26) Niklowitz, W.J.: Ultra structural effects of acute tetraethyl lead poisoning on nerve cells on the rabbit brain, Environ. Res., $8: 17-36,1974$.

27）赤井契一郎, 山田和昭, 内与䛴新也, 河口礼子, 渡辺和 美, 川森正夫, 松井知子, 松本一弥：実験的急性四エ4ル 鉛中毒の中枢神程系病変について, 杏林医会誌, $13: 303-$ 313, 1982.

28) Hong, J., Tilson, H.A., Hudson, P., Ali, S.F., Wilson, E.W. and Hunter, V.: Correlation of neurochemical and behavioral effects of triethyl lead chloride in rats, Toxicol. Appl. Pharmacol., $69: 471-479,1983$.

29) Isaacson, R.L.: The Limbic System, New York, Plenum Press, 1974.

30) Kimble, D.P. : The effects of bilateral hippocampal lesions in rats, J. Comp. Physiol. Psychol., $56: 273-283,1963$.

著者への通信先 : 岸 珨子, T060 札幌市 中央区南 1 条西 17 丁目 札幌医科大学公竬衛生学教室 Reprint requests to Department of Public Health, Sapporo Medical College, Minami 1-jo Nishi 17-chome, Chuo-ku, Sapporo, 060 Japan (R. Kishi) 